\title{
The Cuenca Amulet: History, Magic, and Manuscripts
}

\author{
Eleazar Gutwirth* \\ Tel-Aviv University
}

El amuleto de Cuenca: historia, magia y manuscritos.- Reproducido frecuentemente por su atracción visual y colorido, el amuleto de Cuenca forma parte integral de un legajo de Inquisición conservado en el Archivo Diocesano de Cuenca. Se presenta aquí el testimonio inédito acerca del amuleto y se plantean también algunos de los problemas que suscita: identificación de los personajes; estado del hebraísmo hacia 1496; cuestiones de texto e imagen; conocimientos del judaísmo entre los conversos después de la expulsión; singularidad de la evidencia archivística frente a los amuletos judíos sin fecha y lugar.

PALABRAS ClAVE: conversos; hebraístas; romanceamiento; Biblia; Renacimiento; amuletos; magia; Inquisición.

Frequently reproduced because of its visual attraction, the colourful Cuenca amulet cannot be understood without the rest of the Inquisition file of which it is an integral part. The unpublished testimony accompanying the amulet, preserved at the Archivo Diocesano de Cuenca, is presented here. An attempt is made to tackle the problems it raises: identification of the individuals mentioned in it; state of Hebraism ca. 1496; questions of text and image; knowledge of Judaism amongst Conversos; particular quality of archival evidence in contrast with most Jewish amulets which lack date or place.

KeYwords: Conversos; Hebraists; Translation from Hebrew into Romance; Bible; Renaissance; Amulets; Magic; Inquisition.

\footnotetext{
"gutwirth@post.tau.ac.il
} 
Section 7 of legajo 698 at the Archivo Diocesano de Cuenca ${ }^{1}$ consists of two parts. The first is a testimony or report written down by the Inquisition's notary and witnessed by two individuals. The second is a polychrome amulet in Hebrew characters measuring about $25 \times 25 \mathrm{~cm}$. This second part was analyzed in a paper on magic in fifteenth century Spain. ${ }^{2}$ The first unpublished part is here presented in an appendix.

\section{I}

The tribunal of the Inquisition of Cuenca seems to begin in January 1489, according to the Cédula Real of 28 January 1489 sent to the city councils of the bishopric of Cuenca. This is a period of particular severity and intensity in its activities. The first Inquisitors were the licenciados Francisco Flórez and Bartolomé de Gumiel; its prosecutor, Fernando Sánchez de Frexno; the notaries were Cristóbal Rodríguez de la Parra and Rodrigo Álvarez de Funes; the alguacil, Hontañón de Ángulo.

Our document, however, dates from some years after this. The Inquisition's inquiry seems to have been initiated by two persons from outside of Cuenca. The first individuals mentioned by title but not named in the document are the archbishop of Messina and the bishop of Lugo, General Inquisitors. Indeed, when in 1496, Torquemada retired to the convent of Santo Tomás de Avila, there were appointed four general inquisitors: Martín Ponce de León, archbishop of Messina resident in Spain; Iñigo Manrique, bishop of Córdoba; Francisco Sánchez de la Fuente, bishop of Avila; and Alonso Suárez de Fuentelsaz, bishop of Mondoñedo, and later bishop of Lugo and Jaén. According to Concepción Gómez Roán only two of them were active. She bases herself on a Biblioteca Nacional de España

${ }^{1}$ On the importance of the Archivo Diocesano de Cuenca for Converso history see, amongst various other publications by him, C. Carrete Parrondo, Y. Moreno Koch, "De pícaros y picaresca en el judaísmo castellano," Sefarad 61 (2001), 287-297. Legajo 698 contains many other sections, some of which have been studied. See, for example, section 1, in M. J. Ferrero Rodríguez, "Una judaizante procesada por el Tribunal de Ia Inquisición: Cuenca, 1490," Helmantica 47 (1996), 237-245.

${ }^{2}$ E. Gutwirth, "Casta, classe i màgia: bruixes i amulets entre els jueus espanyols del segle xv," in La Cabala (Barcelona: La Caixa, 1989), 85-99.

${ }^{3}$ See for example Ferrero Rodríguez, "Una judaizante procesada," loc. cit. 
manuscript which reads: "De este nombramiento no consta usasen, sino Dn. Martín Ponce, arzobispo de Mecina, y Dn. Alfonso de Fuente el Sauce, obispo de Mondoñedo, que fue promovido al obispado de Lugo." ${ }^{4}$ The Cuenca document is witnessed by two individuals : "bachiller Alonso de Guevara e Rodrigo de Vyvar". A Rodrigo de Vyvar appears in an inquisitorial context sometime later. A power of attorney or appointment concerning the dean of Oviedo was extended at Griñón on the $3^{\text {rd }}$ of April 1528 by the General Inquisitor Fernando de Valdés (1483-1568). It is witnessed by "el señor dotor Rodrigo de Vivar, clérigo de la diócesis de Toledo". . Guevara is to be identified by recourse to another document. Indeed in Avila, on Friday, 17 December, 1490 a demand was presented against Jucé Franco by the "fiscal D. Alonso de Guevara". ' That is to say that four of the people involved in the document (Martín Ponce de León, Alonso Suárez de Fuentelsaz, Alonso de Guevara, and Rodrigo de Vyvar) are connected to the circles of Tomás de Torquemada who initiated the La Guardia trial. This sets the document apart from the numerous Cuenca Inquisition cases.

II

The analogy or comparison to the Taylor-Schechter Genizah fragments of magic texts ${ }^{7}$ begun in the first study of the Cuenca Hebrew amulet is valid but partial. It may give the impression of an indistinct field of frequent and common identical magical practices, where Cairo, Toledo or Prague are indistinguishable. Indeed, the numerous sources from the Bible and Talmud and onwards that were adduced to explain the Cuenca manuscript would reinforce the impression of continuity and universality. ${ }^{8}$ In general, the amulets or talismans are

${ }^{4}$ C. Gómez Roán, "Notas sobre el establecimiento de la Inquisición española," Revista de la Inquisición 7 (1998), 323-331.

5 J. L. González Novalín, El inquisidor general Fernando de Valdés (1483-1568) (Oviedo: Universidad de Oviedo, 1968), 4-6.

${ }^{6}$ F. Fita, "La verdad sobre el martirio del santo Niño de La Guardia, ó sea el proceso y quema (16 Noviembre, 1491) del judío Jucé Franco en Ávila,” Boletín de la Real Academia de la Historia 11 (1887), 7-134: 8.

7 Gutwirth, "Casta, clase i màgia," loc. cit.

8 Evidently, some common elements cross chronological and geographic or religious boundaries. A fruitful future line of inquiry could be the comparison with the 
not particularly known for their precise dates and places, i.e., the fundamental coordinates in any historical inquiry. Frequently the dating is uncertain or very broad and the location where they are found is not guaranteed to be that where they were produced. It is therefore comprehensible that the usual disciplinary approaches come from fields other than history, where precision in matters of date and place are not the main concern or priority: folklore, psychology, religious studies and -mainly- philology. Despite their encompassing titles (e.g. Jewish Magic), works which are still constantly referenced today, such as Trachtenberg's are not universal. They are in practice highly biased towards the smaller Jewish communities in Franco-German areas and their offshoots, and offer little on late medieval Spain; the use of archives is not contemplated. Similarly and unintentionally misleading might be Schire's work ${ }^{9}$ which is based on a collection of rather late amulets mostly from the modern period but is sometimes read as if it were of supratemporal and universal application. Despite the particular quality of such evidence there is a curious, if not contradictory, desire for historicity; hence questions such as: Who was the public of these amulets and who was not? Were there class distinctions? How do they reflect contacts with other cultures?

That is why the archival evidence (not only of Cuenca) mentioned in the first article on the amulet contrasts so markedly with the undated and unlocated mass of amulets: it offers precise dates, names, city, profession, title of the wearer. This is neither frequent nor common in other remains.

Arabic materials from medieval Spain. Thus, the Tarazona amulet has theophoric names of angels ending in -el and, also, like the Cuenca amulet, what Millás terms a cenefa. Compare J. M. Millás Vallicrosa, "Un amuleto musulmán de origen aragonés," $\mathrm{Al}$ Andalus 6 (1941), 317-326. Similarly, a few common elements may be found in the magical texts studied by José Martínez Ruiz y Joaquina Albarracín. See J. AlbarRacín NAVARro, "Un alherze (receta mágica) contenido en el Misceláneo de Salomón," DYNAMIS. Acta Hisp. Med. Sci. Hist. Illus. 21 (2001), 133-140; J. MarTínez Ruiz, "Ensalmos curativos del manuscrito árabe Misceláneo de Salomón de Ocaña (Toledo) en el marco jurídico de convivencia de las Tres Culturas," en II Congreso Internacional Encuentro de las Tres Culturas, Toledo (1983), ed. C. CArrete Parrondo (Toledo: Ayuntamiento, 1985), 217-227.

9 T. SchiRe, Hebrew Amulets: Their Decipherment and Interpretation (London, 1966). 
III

The question of Cuenca and the Hebraism of the Conversos could be said to have been raised and initiated, in a way, by Dimas Pérez Ramírez. ${ }^{10}$ Studying the Church of Santa María la Nueva in Cuenca, he wondered whether the numerous Conversos who used it -till 1489- would have been able to read the Hebrew inscriptions on its walls (biblical verses from Deuteronomy), or whether they had someone read the Hebrew for them. This period is very close to that of the Complutense Polyglot Bible (begun in 1502) and may correspond to the years of Cisneros' putative studies of Hebrew in Siguienza as well as the activities of famous Converso Hebraists such as (Abraham Seneor's relative) Pablo Coronel or Alfonso de Zamora. It has recently been argued that despite the high number of publications on such personalities, not all Hebraists were the same and there may be some distortion in the focus on the best. ${ }^{11}$ The Cuenca document may give us a more nuanced vision of Christian Hebraism on the threshold of the sixteenth century.

The non-Hebraists know (or assume they know) who is a Hebraist. The practice of searching for Hebraists and relying on "consultancies" that we see in the Cuenca document is familiar because of its continuity: almost at random, one is reminded of the find of the Hebrew characters dowry document of Trijueque ${ }^{12}$ and the way it was treated. It is not always clear in the Cuenca document who is the expert Hebraist, who is reporting on the amulet (cf. "non sabemos qué dizen"), Juan or Alonso. The choice of a maestre, a physician, as consultant for an amulet may be significant (not only because so

10 D. Pérez Ramírez, "La sinagoga de Cuenca, Iglesia de Santa María la Nueva," Cuenca 19-20 (1982), 47-78.

${ }^{11}$ E. Gutwirth, "History, Poetry and the Trilingual Question in Habsburg Spain," Caliope: Journal of the Society for Renaissance and Baroque Hispanic Poetry 17 (2011), 67-93.

${ }^{12}$ F. FITA, "Carta dotal hebrea del siglo xv (21 octubre 1473)" Boletín de la Real Academia de la Historia 47 (1905), 309-312: "En 1. ${ }^{\circ}$ de Julio de 1573 halló el original de ella un labrador en un arcaduz, en un cimiento de una pared. Es un pergamino muy viejo, escripto en hebreo con letras y labores en torno de él. Trájola á Francisco de Medina vecino de Guadalaxara; el qual la llevó á el Maestro Cámara, Rexente de hebreo y caldeo en la dicha Universidad para que la interpretase. El qual lac interpretó en la manera susodicha. Y yo, Francisco de Montalvo soy testimonio". 
many physicians with Christian names were Conversos): amulets were frequently discussed in halakhic texts in a medical frame. But today, after recent discoveries, we are no longer limited to general (e.g. Near Eastern) examples of the specific links between magic and medicine in Hispano-Jewish communities of the fifteenth century and their descendants. Since the $1970 \mathrm{~s}^{13}$ we are aware of an unknown genre of Genizah fragments of Fachliteratur in Judeo-Spanish: manuscript receptaria in Judeo-Spanish. The link between medicine and magic was clear and established: the manuscript of medical prescriptions for hemorrhoids and woodworm contained a pentagram, angelic names and a tetragrammaton.

When they discuss the "Nombre de Dios de cuatro letras", the witnesses, though bearing Christian names, are reluctant to pronounce or write down the tetragrammaton. They know what the Jewish traditional alternative reading is, but elide the full implications of this knowledge with a vague "se dize". This raises the question as to what precisely would or could be known by two individuals with Christian names about the tetragrammaton and how that knowledge would have been obtained in the last years of the fifteenth century. It is therefore relevant to take into account that in medieval Spain the topic of the tetragrammaton was being discussed in romance vernacular texts long before Reuchlin, Heredia or Galatinus. ${ }^{14}$ The "Name of four letters" is extensively discussed in the vernacular in Abner of Burgos'

${ }^{13}$ My preliminary description of the medical/magical manuscripts which I prepared after the find, appeared in print in the Jewish Chronicle, October $9^{\text {th }}, 1979$ along with the description of Campanton's Judeo-Spanish responsum on interest. I later published it again in E. Gutwirth, Ten Centuries of Hispano-Jewish Culture (Cambridge, 1992), 24. For the historical context of this manuscript, see also IDEM, "Sephardi Culture of the Genizah People," Michael 14 (1997), 9-34: 24n39. The edition is in IDEM, "Genizah Fragments in Judeo-Spanish,” Anuario de Filología 9 (1983), 219-223.

14 Obviously, the Latin tradition is more commonly known to a broader public and frequently referred to: J. CARRERAS ARTAU, "La Allocutio super Tetragrammaton de Arnaldo de Vilanova," Sefarad 9 (1949), 75-105; J. M. Millás Vallicrosa, "Nota bibliográfica acerca de las relaciones entre Arnaldo de Vilanova y la cultura judaica," Sefarad 16 (1956), 149-153; E. CoLOMER, "La Interpretación del Tetragrama bíblico en Ramón Martí y Arnau de Vilanova," Miscellanea Mediaevalia 13 (1981), 937-945. F. SECREt, "Les débuts du Kabbalisme chrétien en Espagne et son histoire à la Renaissance," Sefarad 17 (1957), 36-48. 
works and it continued to be discussed by other late medieval authors in the vernacular, the language of maestre Juan and Alonso Pérez and the Cuenca document. These Hebraists in the 1490s explicitly create a description of Hebrew magic amulets as being rooted in Talmud and Kabbalah and as being specifically Jewish. Whatever the merits of such a description of "Jewish Magic", it does exhibit a certain historicist perspective which is not found in the amulets themselves and which persisted in the discourse on Hebrew amulets.

The witnesses decide that in the Cuenca amulet there is a "primer círculo" referring to the center, although the circles are not numbered. They may have had some experience of Hebrew amulets. Some of the components of the amulet are not accessible to them: "no se entienden ver", or "debaxo e encima de cada nombre de estas planetas están ciertos nombres que non sabemos qué dizen", and these formulae were not read by them or since. They do not explain nor mention the magical numbers square. ${ }^{15}$ The expression "letras gordas" does not seem to stem from medieval romance vernacular descriptions of Hebrew writing ${ }^{16}$ and is highly reminiscent of the Hebrew 'otiyot gasot (or ketivah gasah), a legal category within the laws of writing the Scroll, divorces, testimonies. It is doubtful whether "Old Christian" Hebraists at this date would use such a technical term.

The space of the amulet is perfectly organized and proportioned and must have been prepared and divided before the writing. The center is marked by equidistant circles. They were evidently done with a compass. Generally, such circles are understood as standing for cosmic wholeness. Their number, seven, is not accidental; neither is that of the "planets": four. The concentric circles are smaller in the middle. The various rectangles create a border or cenefa. The rosettes in the circles are a frequent feature of medieval Hebrew manuscripts and they have ancient roots (cf. Beth Alfa). Sometimes it is reasonable to argue that they are related to the text (e.g.,

${ }^{15}$ For the magical square see GutwiRTh, "Casta, classe i màgia," loc. cit., 92.

16 "Letras gordas y letras góticas son las maçorrales y de hombres de poco ingenio," writes Covarrubias in the seventeenth century (cf. his Tesoro de la lengua castellana $o$ española, s.v. 'letras'), but in the fifteenth century it does not seem to be a common and well attested expression in the Christian description of Hebrew letters.

17 E. Gutwirth, "Temas setenarios," Estudios mirandeses 25 (2005), 80-97. 
when they are contiguous to the word shoshan); sometimes they are interpreted as symbols of rebirth, but here they may have ornamental functions.

\section{IV}

The Psalm 91, one of the fragmentary biblical romanceamientos present in the amulet, has been noted for its particular anti-demonic character in the first study of this amulet. ${ }^{18}$ It may be added that its words and content have always made it apt for apotropaic use and that this use can be found as early as the incantation bowls or Qumran fragments not mentioned by Trachtenberg ${ }^{19}$ or Schire. The feature of adding angelic and planetary names is not marginal but apparently essential to the actualization of the names. ${ }^{20}$ The question of the angels could be treated as supratemporal and universal and impossible to frame historically. And yet, this is roughly the period when the Castilian Abraham ben Eliezer ha-Levi, the Salamancan Abraham Zacut's brother-in-law felt the need to write his essay or brief treatise on the question of addressing the angels in prayers: Hora'ah 'al she'elat ha-malakhim. ${ }^{21}$ The Christian witnesses may have misread or read inaccurately the angelic names which they (or the notary) render as "Tanuniel, Yofiel, Haziel”.

The translations of the biblical passages seem to be spontaneous. Without a full confrontation, it may nevertheless be useful to compare them to both, Christian and Jewish vernacular translations. Thus, maestre Juan and Alonso Pérez translate Psalm 91 as

Dios abastado, mi abrigo e mi estilo, mi Dios que me esfuerço en Él, que Él te escapará de lazo armado de pestilencia secreta, Adonay te escapará sobre la mano derecha [..., guárdame como la niñeta del ojo], en la sonbra de tus alas me encubrirás.

18 Gutwirth, "Casta, classe i màgia," loc. cit. See also E. DAvis, "The Psalms in Hebrew Medical Amulets," Vetus Testamentum 42 (1992), 173-178.

19 J. Trachtenberg, Jewish Magic and Superstition (Philadelphia: Jewish Publication Society, 1939).

20 G. Scholem, "Havdala de-Rabbi Aqiva- A Source for the Tradition of Jewish Magic During the Geonic Period” (Hebrew), Tarbiz 50 (1981), 243-291.

${ }^{21}$ G. FALK “Hora'ah 'al she'elat ha-malakhim,” Kerem Hemed 9 (1856), 141-148. 
Valera reads the same as:

El que habita al abrigo del Altísimo, Morará bajo la sombra del Omnipotente. Diré yo a Jehová: Esperanza mía, y castillo mío; Mi Dios, en Él confiaré. Y Él te librará del lazo del cazador, de la peste destruidora. Con sus plumas te cubrirá, y debajo de sus alas estarás seguro: Escudo y adarga es su verdad. No tendrás temor de espanto nocturno, ni de saeta que vuele de día; ni de pestilencia que ande en oscuridad, ni de mortandad que en medio del día destruya.

Ferrara has on the same:

Están en encubierta del Alto, en solombra del Abastado manirá. Diré a A. mi amparo y mi encastilladura, Dio mío, enfiuzarmee en Él, porque Él te escapará de lazo enlazante, de mortandad de quebrantos. Con su ala cubrirá a ti y debaxo de sus alas te abrigaraz, pauez y rodela su verdad. No temerás de pauor de noche, de saeta (que) abolaré de día. De Pestilencia (que) en tiniebla anda, de rajamiento (que) destruye en las siestas.

Finally, the Siddur tefillot offers:

Están en encunta de alto en solombra del Abastado será asolombrado digo a Adonay mi feuzia y mi red mi Dio enfiuziarmee en Él. Que Él te escapara de lazo de encampador, de mortandad de quebranto. Con su peno la manparará a ti y de son sus alas te abligarás, adaraga y escudo su verdad. ${ }^{22}$

In the Cuenca testimony "abastado," "esfuerzo," "te escapara," "Adonay" are some examples of possible contacts with the Jewish tradition of vernacular Bible translations.

Recibido: 08/10/2013

Aceptado: 18/12/2014

${ }^{22}$ M. Lazar, Siddur Tefillot: A Woman's Ladino Prayer Book (Lancaster, CA: Labyrinthos, 1995), 86. 


\begin{abstract}
APPENDIX
February 6, 1497, Archivo Diocesano de Cuenca, Inquisición, leg. 698, no. $7^{23}$

En Ávila seys días del mes de febrero de mill e quatrocientos e noventa e siete años, por mandado de los muy reverendos e maníficos señores, los señores arçobispo de Mecina e obispo de Lugo, inquisidores generales, maestre Juan, médico, e Alonso Peres, veçinos de Cuenca, vieron una nómina escrita en ebrayco e dixeron que lo que se contenía en ella es lo siguiente:

Que dize en las letras pequeñas del primer çírculo un nombre de Dios de cuatro letras que se dize 'Adonay'.

E que en el mismo çírculo están ciertos nombres que no se entienden ver.

E que luego dize en el mismo çírculo dize: 'ampara por él e por sus hermanos e su mujer e todos sus consegeros e sus seruidores e sus amigos'. Dize más: 'Adonay te guarde de todo mal; guarde a tu alma; Adonay guarde tu entrada e tu salida, de agora fasta syenpre'. E que en el mismo çírculo están otras cosas que no se pueden leer.

Yten, que en otro çírculo dize: 'Dios abastado, mi abrigo e mi estilo, mi Dios que me esfuerço en Él, que Él te escapará de lazo armado, de pestilencia secreta. Adonay te escapara sobre la mano derecha'.

Lo que está en los quatro rencones de la nómina son quatro nombres de platenas [sic], que cada vna es en su çírculo: que la vna se llama Júpiter, la otra es Venus, la otra Marte, la otra Sol. Debaxo e encima de cada nombre de estas planetas están ciertos nombres que non sabemos qué dizen.

En el çírculo de enmedio en letras gordas dize asy: 'En el nombre de Tanuniel, Yofiel, Haziel', que son nombres no saben de quién. Alrededor deste çírculo dize así: 'Yo vos conjuro que le pongáys gracia e misericordia e piedad al que trae esta nomina sobre sy'.

Alderedor de vn çírculo de los quatro dize: 'Y Noe halló gracia delante Adonay, así alcance gracia y misericordia el traxere esta nómina sobre sy, e todo lo que fiziere a prouecho'.

Alderedor de otro çírculo de los quatro dize: 'E fue Adonay con Jusep, e fue varón aprouechador, asy aproueche el que traxere esta nómina sobre sy, guárdame como la niñeta del ojo, en la sonbra de tus alas me encubrirás'.

El otro çírculo no se puede leer.

En vn pedacito della: 'Alcance gracia Yuçé en mis ojos'.
\end{abstract}

${ }^{23}$ I should like to express my gratitude to Prof. C. Carrete Parrondo who discovered the document for his generous paleographic help. 
E que otras cosas están en la dicha nómina que no se pueden leer.

Luego el dicho señor tomó e recibió juramento en forma de derecho de los dichos maestre Juan, médico, e Alonso Peres, vecinos de la dicha cibdad de Avila [sic] so cargo del qual le preguntó que dixesen e declarasen sy avían sacado fielmente lo que en la dicha nómina se contiene [...], e dixo que él vio la nómina e que la romancearon e sacaron della todo lo que se puede sacar, como esta contenido desta otra parte. E que aquella nómina es abto judaico e de judío e los judíos la trayan, e que al que la traya, este testigo no lo ternía por christiano, sino por judío e que fue sacada la dicha nómina de la Cábala.

E [...] Alonso Peres so cargo del juramento dixo qu'él a lo que él pudo alcançar sacó fielmente lo que en la [...] nómina se contenía como desta otra parte está escrito; e que la [...] nómina es judiega e este testigo por tal la tiene, e que aquellas nóminas semejantes trayan e que al que la trajo consigo este testigo lo tiene por judío e no por christiano. E que fue sacada la [...] nómina del Talmud e de la Cábala.

Testigos que fueron presentes al [...] juramento: el bachiller Alonso de Guevara e Rodrigo de Vyvar e [...] secretario del Consejo de la Santa Inquisición. 